\title{
Amish Workarounds: Toward a Dynamic, Contextualized View of Technology Use
}

\author{
Lindsay Ems ${ }^{1}$ \\ Doctoral Candidate \\ Department of Telecommunications \\ Indiana University
}

\begin{abstract}
Interviews with northern Indiana Amish business owners reveal a tendency to create complex technological workarounds that allow them to abide by shared religious values while remaining competitive in the marketplace. These observations support theoretical approaches to understanding Amish technology use that view technology use as socially contextualized, dynamic and contested. It draws on literature from science and technology studies which views technology as an artifact that is socially constructed. The participants in this study report struggling to manage tensions between maintaining economic stability and traditional family, community, and religious values when deciding whether or not to adopt new technologies. These Amish entrepreneurs feel technology use must be possible but should also be complicated in today's world. Two categories of workarounds emerge from the analysis of interviews: limitations on use and use via a trusted non-Amish person. These two categories illustrate interactions of economic forces, religious values, and professional tradition. In this way, technology adoption is seen as situated in a particular social context and functions as a signal of one’s “Amishness” or association to an Amish identity.
\end{abstract}

\section{Keywords}

Amish; technology; workarounds; northern Indiana 


\section{Introduction}

This article draws on interviews with successful northern Indiana Amish business owners and church leaders to investigate the changing role of technology in their lives. In particular it interrogates conceptualizations of Amish technology use in order to better understand the role technology plays in the evolving construction of Amish identity. As many scholars of Amish culture have already noted, members of Amish communities are not anti-technology (Kelly 2010; Kraybill, Johnson-Weiner, and Nolt 2013; Rheingold 1999; Umble 1996; Wetmore 2007; Wueschner 2002). In fact, many of the restrictions placed on technology use in Amish communities have resulted in ingenuity and technological innovation (Kelly 2010; Kraybill Johnson-Weiner, and Nolt 2013). Additionally, Amish communities vary drastically with regard to which technologies are accepted and which are not (Hurst and McConnell 2010; Kraybill 1994). Thus, scholars should resist re-inscribing their reports with popular stereotypes when it does not accurately depict the experiences of Amish informants. As Amish technology analyst Jameson Wetmore (2007) observes, "stereotypes obscure the intricacies of Amish life" (13). In this article, the experiences of Amish informants are composed and culled to present a theoretical analysis of Amish technology use that reflects the intricacies of everyday life and attempts to avoid generalizations and stereotypes.

\section{Variance in Conceptualizations of Amish Technology Use}

Because, for the Amish, connection to the rest of society is often mediated by technologies, they have a long history of deciding which new technologies to accept and which to reject. Members of Amish communities do not take a hard line against all new technologies. Generally, they do reject public electricity, television, radio, automobiles, and modern clothing fashions. However, among the diverse population of Amish today, it is not uncommon to see people rollerblading, families enjoying time on the lake in a motorboat, construction workers using power tools, homes with solar panels on the roof, businesses with websites and Facebook pages, and Amish using cell phones to talk and send text messages. Though at first glance these choices may seem contradictory, they are actually optimizing their connection to the outside world. In making a decision about adopting or rejecting a technology, they ask whether or not it will create a link over which corporate and governmental control can freely reach in and dismantle the cultural ties that bind their small communities together.

Many social and cultural analysts have observed and documented Amish technology use in a variety of ways. For example, communication technology writer Howard Rheingold (1999) observed how Lancaster County Amish came to make decisions about adopting information communication technologies (ICTs) in the late 1990s. He noted that the social health of the community is the primary focus when collective decisions about technology adoption must be made. He realized that technologies were not just tools for communication, they were symbols that represented philosophies and separation from the outside world. For example, when he asked one Amish workshop owner what he thought about technology, he said that "the Amish 
fear assimilating the far more dangerous ideas that 'progress' and new technologies are usually beneficial, that individuality is a precious value, that the goal of life is to 'get ahead.'” It is this mindset, not the specific technologies, to which Amish most object. His encounters with Amish business owners taught him a lesson about the role of technologically mediated communication in the expression of how important a social relationship is to an individual; the way we put technologies to use signals to our families and intimate others the way we prioritize their place in our lives. According to Rheingold, for the Amish, family and community ties are privileged over the individual and this is evident in the ways that technologies are adopted.

Many scholars have focused their investigations of Amish technology use on understanding the differences between Amish and mainstream approaches. Kraybill (2001) suggests that "apparent quirks in Amish practice” are "bargains struck” to survive. The Amish population today, he says, is "squeezed by the pressures of progress" (3) which forces them to struggle between retaining their distinctive identity and thriving economically in a world where they regularly come into contact with their non-Amish neighbors. The evidence of such struggles is comprised of technological choices that seem strange, contradictory, or even hypocritical to outsiders. Kraybill explains some of these "riddles." He suggests that many do not understand why Amish can have modern kitchen appliances as long as they run on propane instead of electricity, why an Amish person can ride in a car but not own one, and why having a telephone is okay as long as it resides outside the house or in an out-building. The crux of the riddle, he says, is their ability to both "resist" and "negotiate" the forces of "modernity": "The traditional side of Amish life, maintained by resistance, tilts back toward the past. But had they only resisted, they would surely be social antiques. By contrast, their willingness to negotiate with modern life reflects an openness to change and progress” (Kraybill 2001, 21). The bargaining process that results from these two forces has resulted in some of the "perplexing puzzles of Amish society that appear silly to outsiders — using telephones but not in the house, riding in cars but not owning them, and using rollerblades but not bicycles” (Kraybill 2001, 24).

Kraybill theorizes Amish technology use along a continuum of modernity where, at one end there is an imagined standardized "traditional" use of technology and at the other a standardized "modern” use of technology. Modernity, he says, is notable for its segmentation of social relationships and activities. Modernization "pulls things apart and partitions whole systems - psychological, social and organizational_-into smaller parts in the name of efficiency" (19). This has the effect of removing relationships among people from a particular social context. "The fragmentation of modern life is often experienced on the personal level as alienation when ties with meaning, work, and place evaporate” (19). Implicit in this assessment is the assumption that there is a coherent typology of technology use that can be pinpointed among a large population of Amish and / or non-Amish individuals.

In his explanation of Amish technology use, Kraybill suggests the Amish preference is to lean toward the traditional end of the continuum whenever possible in making technology choices. Indeed, scholars may use the metaphor of a ladder when discussing Amish communities' 
approaches to technology. The lower a community is on the ladder, the more "traditional" it is and resistant to the forces of modernity (Wueschner 2002). The higher it is, the more likely its members would be to drive cars, adopt modern technology and live like "non-Amish."

From Kraybill's perspective, the Amish see technologies as emblems of modernity, agents of fragmentation, alienation, and decontextualization. The Amish, then, resist photography because a photo pulls people out of context. They reject television because it portrays floating images without context. And, Kraybill says, "Virtual reality on the World Wide Web literally has no context” (19). When things are taken out of context, perspective, meaning, and clarity are lost. The Amish, he says, opt for a more traditional social formation which prefers close-knit, highly integrated community bonds over those sustained by anonymizing technologies.

Cooper (2006) also investigates perceptions of electronic media among Amish leaders. He describes the Amish approach to adopting media technology (or not) as "perpetuating a media fast." Amish leaders view certain technologies as the "unclean thing” not to be touched, from II Corinthians 6:17. Cooper makes a general claim, that across plain communities, electronic media is seen as a threat to family fusion. While it sometimes promotes worthy causes, according to his informants, the evil associated with it often outweighs the good and, thus, it is best left alone. Cooper, like Kraybill, understands Amish approaches to technology adoption as a choice that seeks first to resist the new whenever possible. Only after an effort to resist the technology is made is a decision to accommodate particular uses of technologies entertained.

Others, however, view Amish approaches to technology use as more complex, suggesting that they cannot be completely understood in terms of modernity alone. Wueschner (2002), for example, understands that the allure of modernity is a force that governs Amish technology decisions. However, he feels it is but one of many forces at play in such decisions. In his investigation of technology use in an Iowa community, he finds that increasing population density in Amish communities and changes in the economy also play important roles in the contested relationship between the Amish and technology. Many Amish workers, he says, have left agriculture for new cottage industries where their lifestyles differ only slightly from their non-Amish neighbors. He encountered Amish entrepreneurs who established successful businesses as contractors and retailers, and now only rely on farming as a secondary source of income. These new ventures have changed the lifestyles of the families that work in them. These individuals now visit the same retail stores as their "other world neighbors" and use modern means of transportation to travel long distances to visit relatives, attend funerals, and attend weddings, according to Wueschner. In the winter months, some spend time in Florida, just like their English counterparts.

According to Wueschner, these forces are an attempt to preserve the basic Amish community structure, not to change it. This differs from Kraybill and Cooper, who assume technology adoption reshapes the basic social structure. Wueschner describes a new retail store dubbed “a mini Wal-Mart” that sells dry goods, can goods, some perishables, and hardware 
items. In this recently established business, perishables are kept in a refrigerator powered by a gasoline engine and the electronic cash register is powered by a solar panel mounted on the roof of the store. Skylights provide interior lighting. The owner advertises in non-Amish publications and draws Amish and non-Amish customers alike. The owner established himself in the retail business in order to work near his home. In this case, new technologies and ways of working were adopted in order to maintain a way of life that is felt to adhere to Amish values. The technologies adopted also do not indicate the onset of inherent fragmentation or decontextualization. Nor do they resemble a move toward a static standardized modern, or "nonAmish” point along a continuum. In this case, adopting technologies such as refrigerators, electronic cash registers, and skylights helps the owner stay home and live a "more traditional" lifestyle which aligns better with his family's values. Wueschner's perspective differs from that of Kraybill and Cooper in that the social world in which the Amish are embedded is seen as dynamic and evolving. From Wueschner's viewpoint, technology use is the result of pursuing both values and needs and is situated in and determined by social context, not detached (or creating detachment) from it.

In another investigation, Cong (1992) depicted the struggles and tensions experienced by members of a northern Indiana settlement surrounding the adoption of kerosene refrigerators in the 1980s. In this case, community members were generally favorable toward adopting the refrigerators, but some church leaders disagreed that this was the best course of action. Nonetheless, many churches ended up adopting the refrigerators. Still the decision-making process was wrought with tension and conflict among community members. One conservative Bishop was ousted and a small sector of the church left to form an ultra conservative faction in southern Michigan. According to Cong, in the end, the adoption of kerosene refrigerators helped keep the majority of the community together. The decision to adopt the technology occurred because it did not force individuals to give up "the key features" of Amish culture including those that distinguish Amish from non-Amish people: church service at home, no automobile, no electricity, buggies, use of horse power in the fields, and plain attire made of whole-color fabrics (217). These features have in common the characteristic that they are highly visible and symbolic of Amish identity to both Amish and non-Amish alike. Kerosene refrigerators, according to Cong, are not key features of Amish culture and are invisible except to the small number of people who enter a family's home. Cong's investigation reveals the structured process by which the adoption of a new technology helps maintain community coherence. In this case, the grouplevel ruling that kerosene refrigerators were an acceptable technology to use became a formal symbol of Amish identity in this settlement. The minority moved to Michigan to join a community that also felt kerosene refrigerators should not be a symbol of Amish identity. It is important also to note here that this supports previous findings suggesting Amish identity and the symbols that represent it (accepted uses of technology) differ from one community to the next. 


\section{The Social Construction of Technology}

Scholars in the field of science and technology studies (S.T.S.) offer relevant perspectives to this analysis of technology use and social formations. Seen from a social constructivist view, technologies are inherently steeped in and determined by the evolving social context in which they are designed and used. According to Pinch and Bijker (1984) — the developers of the social construction of technology (S.C.O.T.) theory-technology cannot be understood without taking the social context into consideration from the perspective of the social group in which it is embedded. S.C.O.T. is a theory within S.T.S. that says, to understand why a technology is accepted or rejected in any community, one should look to specific social worlds for answers. This differs from the well-known diffusion of innovation theory outlined by Rogers (2003), which presumes a top-down distribution of ideas and artifacts throughout a particular social structure. Diffusion of innovation measures the rate at which a technology is adopted (or adapted based on culturally specific needs) in particular communities. Where diffusion of innovation theory holds a deterministic view, S.C.O.T. espouses a contingent view. Theorists adopting the S.C.O.T. perspective would reject the notion that technology is value neutral, or at any point becomes decoupled from social context, norms, or politics. According to S.C.O.T., it is not enough simply to say that a technology is accepted because it is "the best," or "most efficient" one available. Researchers must look at how the criteria of being "the best" or "most efficient" is defined by a relevant social group and which stakeholders participate in defining it (Pinch and Bijker 1984).

In S.C.O.T., the developmental process of a technological artifact and its use is seen as an ongoing process of alternation of variation and selection where use of an artifact generates meanings for people. These meanings are re-inscribed in various uses of the tool and eventually influence its design in future iterations. Some variations eventually prevail over others and these become routinized in standard usage (Constant 1980; Pinch and Bijker 1984). Such tendencies are in dynamic interplay, creating a mutual shaping of the tool through cyclical interactions between the artifact and its users over time. Such a multi-directional model of innovation and adoption differs from the linear models previously used in innovation studies. A multi-directional perspective, according to Pinch and Bijker, is essential to a social constructivist account of technology. To exemplify the strengths of S.C.O.T., Pinch and Bijker examine the bicycle and ask why some designs, in the technology's historical development, died out whereas others survived. Their conclusion is that the versions that died out had problems assigned to them by relevant social groups, not that certain designs were better or worse than others per se.

S.C.O.T. offers scholars of Amish technology use a new lens from which to analyze variations in technology adoption because it begins from the assumption that all technology use is shaped by the social context of its creators and users. It complicates the assumption that technology itself perfectly maps on to a continuum. It problematizes the notion that all Amish, or non-Amish, use computers, phones, or other technology in uniform ways removed from a wide 
range of overlapping social contexts. It also introduces the opportunity to examine the role that values, politics, power, and ethics play in the adoption of technologies. These are particularly important for the study of Amish technology adoption because, as Kraybill and others have noted, it is highly symbolic and plays an important role in the communication of a shared Amish identity which serves to protect them from assimilation into mainstream society.

Diane Zimmerman Umble (1996) conducted a detailed study of Amish technology adoption using a S.C.O.T. perspective, though not specifically identifying it as such. Her investigation explored the reorganizing capacity of the telephone among Old Order Amish in Pennsylvania and the struggles faced among communities. Zimmerman-Umble studied the changes in social practices accompanied by the introduction of the telephone over the course of the twentieth century and the conflicting meanings members of the Amish community associated with them. She explicitly sought to avoid falling into the traps that adopting a more deterministic view of technology's impact on society elicit (1) the habit of interpretation through sweeping metaphors, (2) assuming homogeneous effects of technology on society, (3) assuming that a technology's consequences are linear and (4) that a technology impacts society by transferring its properties to individuals, groups or institutions. She found that over time the shared meaning of the telephone changed from being seen as a threat to being seen as a necessary tool for business with the outside world and for communication with doctors and friends and family (both in and outside of the church community). Zimmerman-Umble's study marks the changes in how members of the Lancaster County Amish community understood the telephone over time. Her study additionally supports the plea for understanding the relationship between technology use and Amish social formations as contingent, embedded in specific power structures and dynamics.

\section{Workarounds}

In the following section, a particular pattern of use will be explored. Namely, the workaround will be interrogated as a concept that can help describe certain approaches to Amish technology use advancing the theoretical considerations above. The workaround, as an academic concept, has been most thoroughly developed in the field of health informatics where it helps organizational ethnographers of technology understand the unanticipated modifications users make to a technologically mediated communications system. Most often, the context for the study of workarounds is in hospitals where all-encompassing emergency medical record systems have recently been installed. In defining the concept, Fernely and Sobreperez (2006) say a workaround emerges, "where a mismatch occurs between the expectations of technology and actual working practice” (3). Employees, they say, may implement a workaround by deviating from set procedures. The notion of workaround is further explained by Kobayashi, et al. (2005) as “informal temporary practices for handling exceptions to workflow.” Unfortunately workarounds have not been significantly developed outside the literature of this limited domain. For the Amish, the concept will be extended here to describe a unique use inspired by a shared value system. In other words, for the Amish a workaround is a particular use of a technology that 
reflects local values and is determined by social context. The adoption of a workaround also is seen here as signaling one's Amishness or shared group identity.

The workaround is a useful concept for understanding the motivations of Amish businessmen in designing communication flows through their peculiar uses of technologies because it reveals the motivations of the user in their interaction with a larger global communication system. The workaround highlights differing logics that underscore communication flows among various groups of people. Motivations for creating workarounds may be political, cultural, or functional, or a combination. The workaround provides a point at which users have agency to change the system to work better for them, according to their values and needs. Thus, workarounds can be used as an observational mechanism, which stands to reveal local values to the social analyst and reproduce Amish identity in practice. As organizational science scholar, Donald Norman (2008), notes, “workarounds are truly revealing both in needs and solutions.” Field visits to northern Indiana have yielded observations of a number of technological workarounds in Amish work and home life. These allow individuals to abide by their religious values, protect close-knit social bonds, acquire financial resources, and help communicate what it is to be Amish to community members and outsiders alike.

Because it is more often through technologies that the Amish interface with the outside world, their unique uses of technologies reveal a great deal about their relationship to the larger society. When a workaround is developed, receives church approval, and diffuses throughout Amish communities, it signals an approved pathway that can be opened and closed to interact with the outside world for certain reasons. While many outsiders think the Amish flatly reject new technologies, members of Amish communities are actually less worried about the technology itself and more about the impact the content flowing over it could have on the closeknit relationships that have formed over generations within the local church community.

Northern Indiana Amish technology use, then, reflects a desire to protect natural groupings like family, community, and church. When a new technology does not threaten these groupings, it is more likely to be adopted. In some cases, however, compromises must be made to ensure that Amish businesses maintain their competitive edge in the capitalist economy today. This paper frames these compromises as workarounds. This is a deliberate choice as the term "compromises" suggests that those making these choices are passive recipients of new technologies and that these stand to imprint a uniform change on the social structure in which it is introduced. A "workaround" on the other hand conceptualizes the user as active and motivated to act by social norms, individual needs, and communal values.

\section{Methods}

This investigation took place in a large Amish community in northern Indiana in the spring of 2011 and summer of 2012. The data presented here was collected through interviews with Amish entrepreneurs and church leaders and by observing their work during two separate 
field site visits. The name of the towns where the research was done will not be given and names of the individuals have been changed to provide anonymity to participants. Details about the type of work they do have also been altered slightly to prevent recognition of the prominent church leaders and business owners that agreed to participate in this study.

The northern Indiana Amish community is home to the third largest population of Amish people in the country. As is the case in many Amish communities, the economy there is changing. The traditional Amish agriculture industry has given way to the recreational vehicle manufacturing and tourism industries as the dominant economic engines in the region. Participants reported these changes have meant adapting and approaching the use of new technologies in a more liberal manner. The church here, according to one informant, is more accepting of technology adoption than in other Amish communities. In some cases, for example, families have moved out of the area to smaller more remote communities in order to live more "restrained” lives, according to one informant.

In two visits to the field site one participant acted as sponsor and introduced the author to four other business-owners and church leaders who agreed to be interviewed for this study. The data collected was qualitative and ethnographic. All participants were ministers, deacons, or bishops, and all owned their businesses. The author's sponsor, Amos, owned shares (percentages varied from one fifth to full-ownership) in at least three different businesses. Of the businesses the men owned, two were retail shops, one a restaurant, three in the furniture-making industry, one in small machine repair, and two in construction. Among five men, then, there were eight businesses represented. Conversations lasted from thirty minutes to two hours and were aimed at understanding what role technology plays and should play in their work and family lives. Except the sponsor, each was interviewed once. The sponsor and the author communicated many times via email and cell phone and met in person twice, spending about ten hours together in all.

\section{Northern Indiana Amish Workarounds}

In this section the workarounds shared by participants in their work or at home are discussed. Non-I.C.T. workarounds are presented as different from I.C.T. workarounds, though both mediate the Amish relationship to the outside. For example, solar panels today are used in some Amish communities at home to charge batteries and run washing and answering machines. Solar power is presented as a workaround to using electricity from the wired electric grid. It embodies a particular socio-technical arrangement, which the Amish favor over the grid because it protects family bonds and religious values from outside influence. At the same time, electric technologies can be used to fulfill Amish-specific needs according to Amish values and norms.

\section{Non-I.C.T. Workarounds}

\section{Non-Grid Electricity via Diesel Generators and Solar Panels}

Using electricity from the grid is rejected in most Amish communities. In northern 
Indiana, Amish are still using electrical tools powered by self-generated electricity. This power is made by generator or through solar panels, which some have called hooking up to "God's grid."

Leon, a business owner and church leader, was interviewed in his furniture construction workshop. It was quite large with florescent lights and the loud, constant firing of power tools filled the air. In the background at least three young female Amish workers were assembling furniture. The interview at one point was interrupted because a semi-truck driver arrived and wondered to which dock he should back up and unload his delivery. Although Leon reported not having a need for a cell phone (except when he was travelling), the internet, or a computer, his workshop appeared equipped with the most modern woodworking tools. When asked how the lights and tools were powered, the owner and bishop revealed a small shack which housed a diesel generator photographed in Figure 1. When asked about generators at home, the bishop reported having a smaller Honda generator to run his washing machine and wells. When asked why some homes had solar panels, as observed by driving through the area, Leon said they were for charging certain batteries like LED lights for buggies, flashlights, and cell phones.

\section{Figure 1: Industrial Diesel Generator}

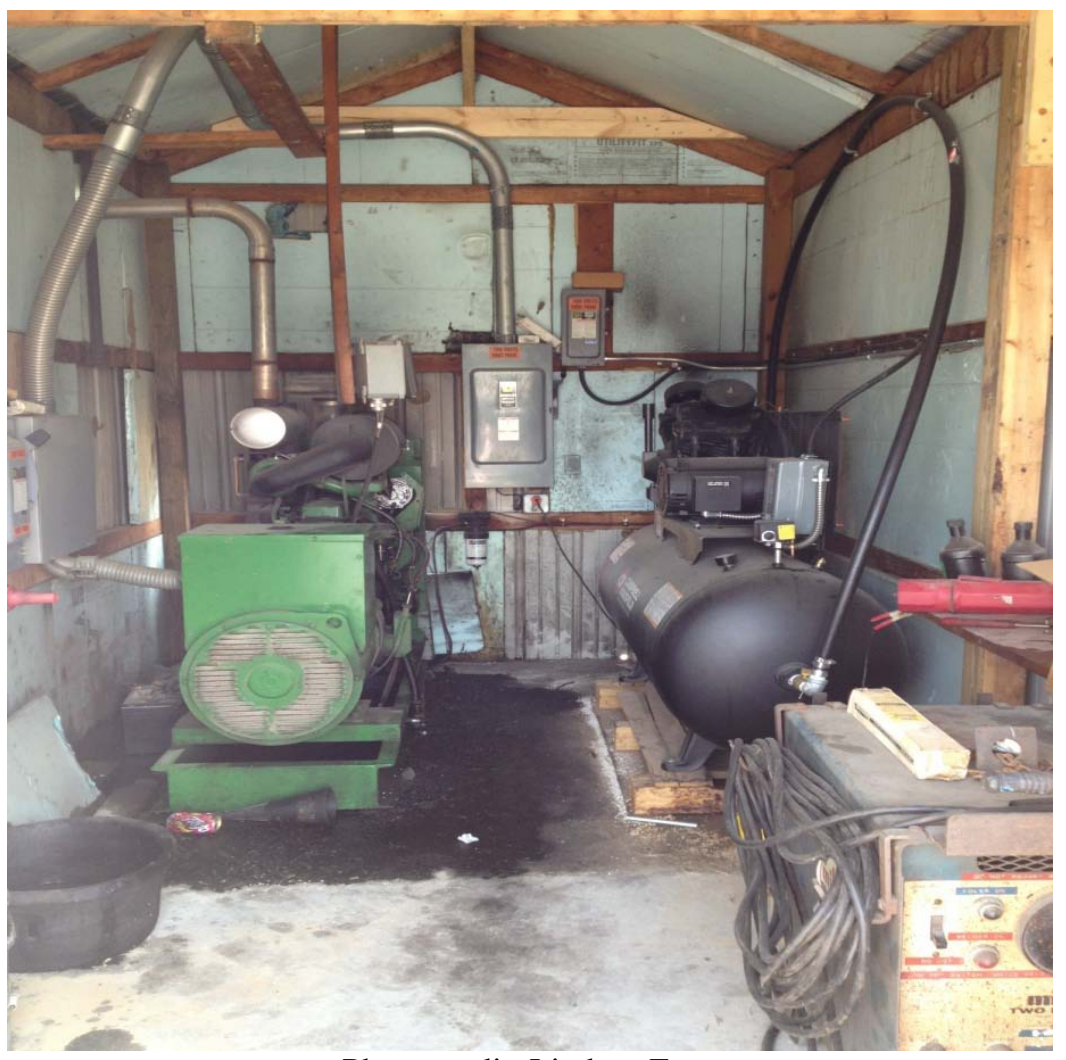

Photo credit: Lindsay Ems 
The workaround employed here is using electricity to power tools that are advantageous for doing certain jobs while rejecting its constant accessibility. This rejection, according to Leon, allows work to get done while still abiding by Amish values. Specifically, it protects family and community bonds from being corroded by outside influences that might enter the home via more dangerous electric devices like television, radio, and the internet. The use of generators or solar panels to create electricity helps symbolize an Amish value that relationships inside the community should be fostered and separation from the outside world should be maintained. Thus, electricity should not be taken for granted and use should be in moderation and only for certain purposes. As a tool for work, it is seen as essential to competing in the modern economy. That the electricity is not "always on," however, means it should only be used for purposes that align with Amish values. That the electricity is optional is symbolic of Amish identity and helps maintain a separation from the way that non-Amish others use electricity and electric tools.

\section{Photo IDs}

Leon also mentioned that his church recently started allowing photo IDs to be obtained and used. Prior to this decision, many Amish had photographic identification cards that did not have pictures on them. Many Amish groups believe that individuals should not be photographed as it creates a graven image. Leon felt strongly that one should not have pictures of family members on the walls at home, as this is against Jesus' teachings in the Bible and helps elevate the individual above the group. Photos of family members at home do not align with Amish values. However, because it recently became impossible to travel to Canada without a passport, he needed a photo ID to travel for work. Because Leon's need was business-related, it was seen as a "tool for work." In this sense, it was not different from the electricity via generator / solar panel arrangement outlined above. The passport was used to make working in today's marketplace possible.

\section{I.C.T. Workarounds}

\section{Cell Phones and the Internet}

According to those interviewed, whether cell phones should be adopted and / or how they should be used by members of northern Indiana Amish churches is currently a debated topic. Of the five men participating in this study, only one reported not having a cell phone that he used on certain occasions. He said he did not have one because in his work, he had more than enough business through word of mouth advertising. A repairman who fixes R.V. motors, he gets all of his business through the local R.V. dealerships. Three of the four men with cell phones reported needing them when they travel for work. Two of the three with cell phones said that travelling for work was the only occasion they used a cell phone.

This study's sponsor, Amos, travels often for work. One of his three businesses requires that he travel across the state to oversee construction sites. He feels his cell phone makes him accessible to customers. "This day and age, people expect to get information right away. If they 
can't reach you, they'll go somewhere else." He thinks he is the same way. "It's just the way society is,” Amos believes. Amos sees himself as an active participant in the global economy. To make money, he and other businessmen needed to adapt to the regional economy and market.

According to this study's participants, the cell phone should be seen strictly as a work tool. Leon said if it was just a cell phone and only for work purposes, "we would not see a problem with it." However, for a smart phone that could access the internet and had a camera attached to it, "we would say, no way. We would see that as more of a toy and less of a tool for work." In this way, the workaround is a social limitation on the tool's use for certain reasons. It is cast into the same category as other tools the Amish have allowed for work purposes while placing limits on the social applications and technical affordances acceptable for Amish use.

One man was interviewed on his lunch break at home. His wife was making cupcakes for the annual church auction that night while their nine week-old son sat near her in a baby seat in the kitchen. On a tour of their house, an interesting piece of technology (Figure 2) was visible on the floor of their bedroom next to their bed, about five feet away from a circular, handmade baby's crib. It appeared to be a car battery with a cell phone charger attached to the top. When the couple was asked about it, they revealed that it was indeed a cell phone charger. The author was struck by how close the phone was to the most intimate place in the family's home. Because telephones are commonly placed outside the home in most Old Order Amish communities so as not to disturb family time, this seemed a noteworthy observation (Zimmerman Umble 1996). More research is needed to better understand how rules and usage of such technologies are changing in Amish communities today and whether such practices are localized or widespread.

\section{Figure 2: Car Battery Cell Phone Charger Next to Amish Couple’s Bed}

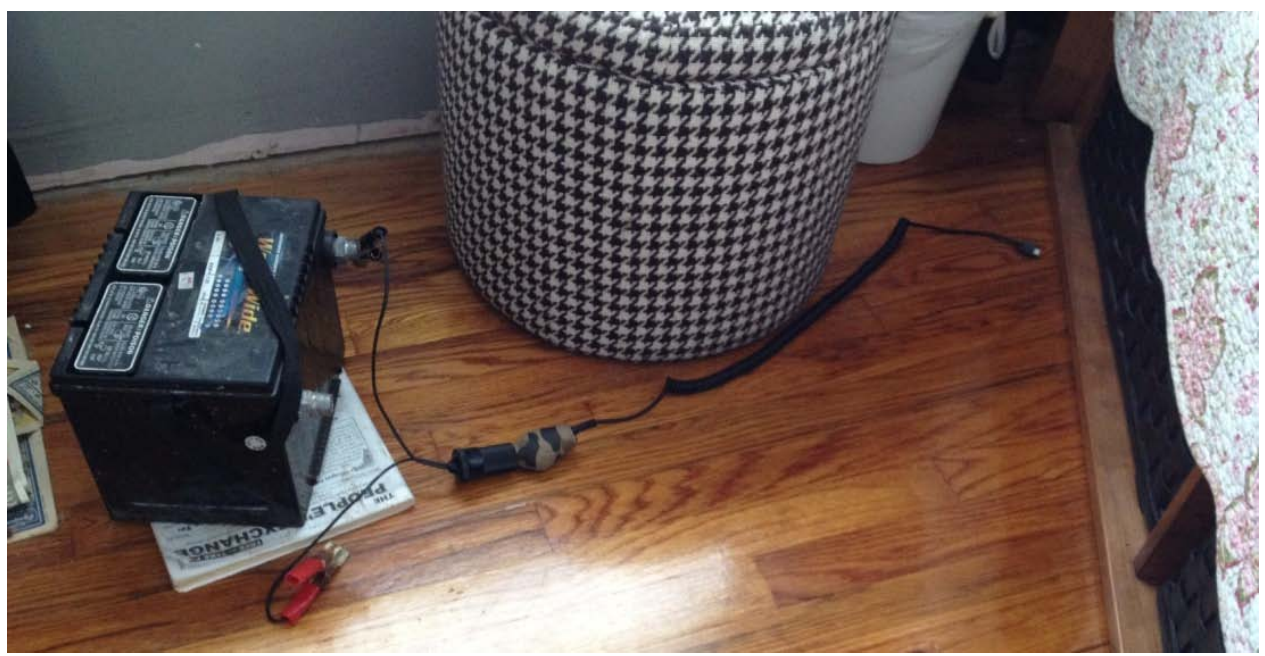

Photo credit: Lindsay Ems 


\section{Computerized Point of Sale Systems}

Amos directed as the author drove through his stomping grounds. He pointed out where to turn while talking on his cell phone. He used his phone to conduct business but also to talk to his wife about their evening plans and about whether he could stop and get a bag of ice on his way home. During a forty-five minute interview with another participant, he came back to the car and had seven new voicemails. A few days before, the building where one of his businesses was located burned down. It was a total loss. While in its place, with the outpouring of help from fellow church members, a new building had already been erected, he still needed to be in touch with people to facilitate the finishing touches.

In transit between interviews, Amos revealed one technology he recently implemented in one of his businesses. A computerized point of sale system was installed his large retail store which sold clothing, souvenirs, and fabrics. He said, at one point he and his five other Amish coowners realized that they had been under-pricing goods and had ended up with a \$200,000 loss. He did not have an organization or inventory system and as their business grew they could not keep up with what their inventory was worth. They were not able to adjust their prices according to fluctuations in inventory prices, because of the quick growth of their business. This, he said, "bit really hard." So, they brought someone in to implement a computerized inventory system using a computer that was "internet-disabled" and point of sale software so that inventory counts would be up to date. This would allow the business owners to know what they had sold. Although, he felt this was the right solution for his business, he and his co-owners were not sure it was the best ethical or religious choice. When he originally came up with the idea of a computerized point of sale system, he suggested it to his fellow owners not knowing how they would react. He is the oldest among them and wanted to act when he realized the $\$ 200,000$ loss. The others, to his surprise, were relieved. They agreed to incorporate the new system right away.

He got a phone call on the day of the interview from a fellow co-owner asking what he thought about bringing on another (non-Amish) co-owner. If they made this person a "majority owner" then they could have a more high-tech business operation, he said. This person could bring tech savvy to the business that was sorely needed among the current owners to help implement the new computerized system. Amos was in support of it. Although, he realized it was a difficult choice, he wanted the business to do well and felt relieved that someone had suggested this possible solution.

Making use of a tool through a non-Amish person was a reoccurring pattern observed in conversations with participants about the use of technologies. For example, in cases of automobile transportation, computer use, internet use, website development, and advertising through radio and billboards, a non-Amish friend or colleague offered to serve as a go-between. When the participants in this study were forced to use these technologies to maintain a competitive edge in business, and they were not sure the decision aligned with their values, they created a workaround of a specific type: they hired a non-Amish person to use the technology for 
them. They reported hiring cars and drivers, relying on young people or non-Amish to file their taxes and do their banking via the internet and computers, to build websites, and advertise their businesses via social and traditional media. They reported trusting and depending on non-Amish to take care of these things for them. This makes things that go against their values harder for them to do, according to Amos. For him, it was like wearing Amish clothes. His clothes, he felt, make it harder for him to show up to places he probably should not go anyway. Similarly, outsourcing to non-Amish people he trusts makes it harder for him to use the technologies he feels he should not use in ways he should not use them.

\section{Conclusion}

Participants in this study reported creating socio-technical workarounds that allowed them to abide by religious values while remaining competitive in the global economy. In today's economy, they are facing new challenges in the acquisition of financial resources while continuing to abide by traditional family, community, and religious values. The particularities of this complex situation have pushed entrepreneurs to use technology in intentionally complicated ways. By examining the particular technological workarounds used by these Amish entrepreneurs, this paper identifies two patterns (1) in which new tools are used, but with certain limitations assigned to their use, and (2) in which new tools are used via non-Amish intermediaries. These solutions act as barriers to the access and use of new technologies by introducing a level of complexity. This complexity is significant as it functions as a reminder of Amish values and symbolizes Amish identity as separate from mainstream society. Leon captures the motivation for the use of these workarounds by saying:

When it comes down to it, we are distracted from living a life for God when we are constantly striving to obtain the next, latest, greatest thing. What people should be looking for is not something that can be gained by acquiring worldly possessions, new gadgets, or by knowing about the latest breaking news. In fact these things prohibit the close bonds we care most about. Limits and controls are essential. It is important to teach people from a young age how to restrain themselves. "No" should be the first word a child learns.

These two approaches have been noted by this study's informants as solutions that are enacted through particular rule-making processes which are also currently undergoing changes to adapt to emerging economic forces and the arising needs of community members. According to the participants in this study, the rule-making processes that give rise to these workarounds involve directly addressing the material aspects of the device when placing limits on it. After a period of improvisation, decisions are often made and diffused through the community. It is at this point that a particular workaround becomes a formal symbol of shared Amish identity in a particular community. This particular rule-making procedure may work well for technologies that have limited functionalities. Looking into the future, however, it is possible such processes will require revision as technologies become capable of performing more varied tasks. 


\section{Figure 3: Amish Technology Decisions, Three Intersecting Vectors}

\section{Limitations on Use Use via an Intermediary}

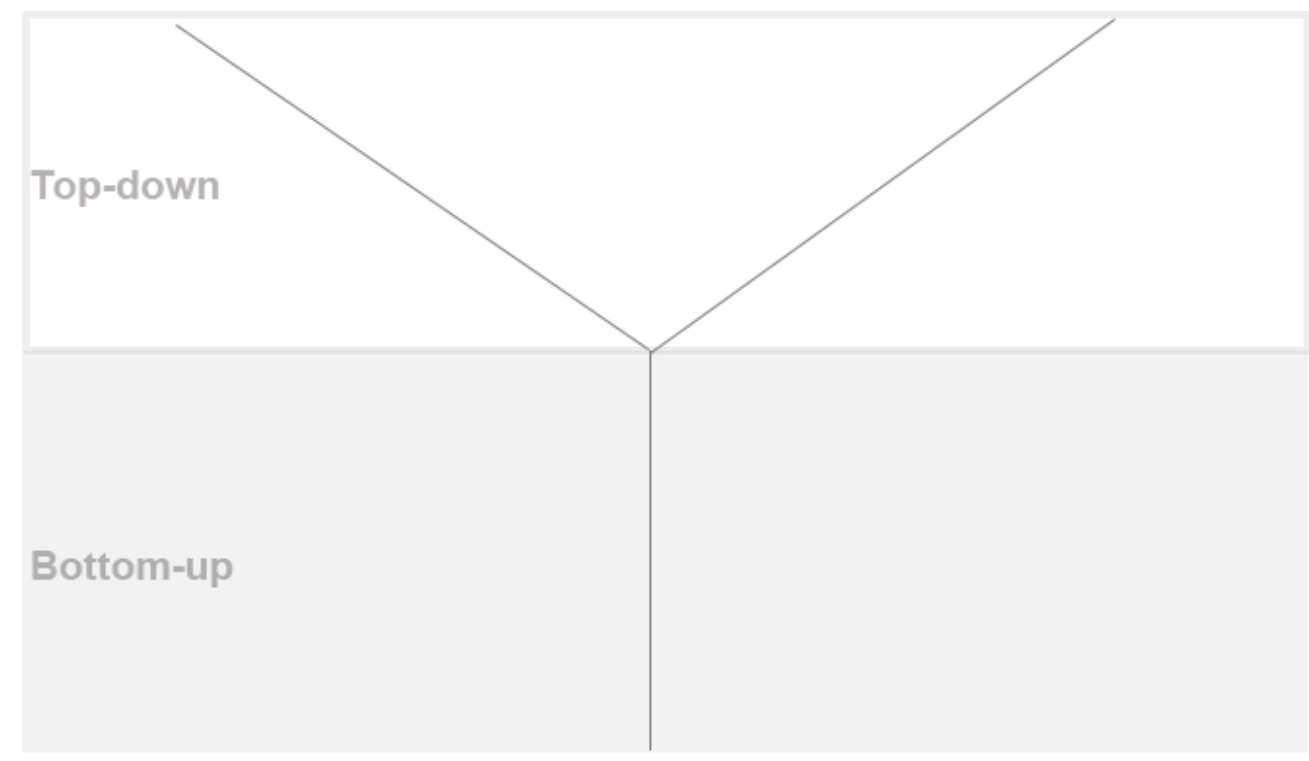

\section{Socialization/Training}

Indeed, tools like smart phones are already an increasing concern among members of Amish communities across the country. In regulating the use of tools that can do many things at once (surf the internet, watch television and films, listen to music, watch pornographic content, etc.), the approach may require a greater emphasis on an alternative element: socialization and training. The men in this study noted that technologies can be used for good or bad. In the future, if business needs continue to spur the adoption of new I.C.T.s like smartphones, social media, and the internet in Amish communities, an increased focus on bottom-up solutions may also be needed to augment existing top-down approaches. By encouraging individuals to teach each other appropriate uses of such tools and to act as role models, social norms may begin to develop and spread from the bottom of the social hierarchy up. In this way, members of Amish communities can learn how to use these tools according to Amish values and beliefs through participating in everyday relationships. Such a proposal can be conceptualized as three intersecting vectors, as depicted in Figure 3. Each of these forces determines technology use in Amish communities and influences the decision-making process. As technologies change, it may be that the point of intersection shifts in a dynamic fashion based on the social context, values, individual motivations, and social norms. This view of the technology adoption in Amish communities, however, assumes that new technologies are adopted in unique ways, and that technologies and their uses are socially constructed in order to preserve the basic social structure of Amish communities. This stands in contrast to other conceptualizations of Amish technology use that view technology as value neutral and / or emphasize an impending uniform change to basic social structures as technologies are passively accepted. 


\section{Endnote}

${ }^{1}$ Contact information: Lindsay Ems, Doctoral Student, Department of Telecommunications, 1229 East $7^{\text {th }}$ Street, Bloomington, Indiana 47405; 812-855-3828 lems@indiana.edu.

\section{References}

Cong, Dachang. 1992. "Amish Factionalism and Technological Change: A Case Study of Kerosene Refrigerators and Conservatism.” Ethnology 31(3):205-214.

Constant, Edward W. II. 1980. The Origins of the Turbojet Revolution. Baltimore, MD: Johns Hopkins University Press.

Cooper, Thomas W. 2006. "Of Scripts and Scriptures: Why Plain People Perpetuate a Media Fast.” Journal of American Culture 29(2):139-153.

Fernely, Elaine. H. and Polly Sobreperez. 2006. "Resist, Comply, or Workaround? An Examination of Different Facets of User Engagement with Information Systems." European Journal of Information Systems 15(4):345-356.

Hurst, Charles, and David McConnell. 2010. An Amish Paradox: Diversity and Change in the World's Largest Amish Community. Baltimore, MD: Johns Hopkins University Press.

Kelly, Kevin. 2010. What Technology Wants. New York: Viking.

Kobayashi Marina., Susan R. Fussell, Yan Xiao, and F. Jacob Seagull. 2005. "Work

Coordination, Workflow, and Workarounds in a Medical Context.” Presented April 2-7 at the ACM 2005 Computer Human Interaction Conference. Portland, OR.

Kraybill, Donald. 1994. "Plotting Social Change across Four Affiliations.”" Pp. 53-74 in The Amish Struggle with Modernity, edited by Donald Kraybill and Marc Olshan. Hanover, NH: University Press of New England.

Kraybill, Donald. 2001. The Riddle of Amish Culture. Baltimore, MD: Johns Hopkins University Press.

Kraybill, Donald, Karen Johnson-Weiner, and Steven Nolt. 2013. The Amish. Baltimore, MD: Johns Hopkins University Press.

Norman, Donald A. 2008. "The Way I See It: Workarounds and Hacks: The Leading Edge of Innovation.” Interactions 15(4):47-48. 
Pinch, Trevor J., and Weibe E. Bijker. 1984. "The Social Construction of Facts and Artefacts: or How the Sociology of Science and the Sociology of Technology might Benefit Each Other.” Social Studies of Science 14:388-441.

Rheingold, H. 1999. “Look Who’s Talking.” Wired 7(1). Retrieved 5 May 2013 (http://www.wired.com/wired/archive/7.01/amish.html).

Rogers, Everett M. 2003. Diffusion of Innovations. New York: Free Press.

Wetmore, Jameson M. 2007. “Amish Technology: Reinforcing Values and Building Community.” IEEE Technology and Society Magazine Summer:10-21.

Wueschner, Silvano. 2002. "Economic Pragmatism: The Iowa Amish and the Vision of Communal Coherence in Late 20th Century America.” Essays in Economic and Business History 20:215-27.

Zimmerman Umble, Diane. 1996. Holding the Line: The Telephone in Old Order Mennonite and Amish Life. Baltimore, MD: Johns Hopkins University Press. 